\title{
The Mathematical Precision of the Bible
}

\author{
Talwanga Matiki
}

mtalwanga@cut.ac.za

\section{Doi:10.5901/mjss.2014.v5n23p2055}

\section{Abstract}

The Bible is the word of God; an account of the creation of the universe, of the relationship God has established with man and of His redemptive plan through a pattern man, Jesus Christ. As a discipline, mathematics plays an interpretive role of explaining, revealing the hidden beauty of numbers and their patterns which are inherent in nature. It does so through nonrefutable axioms, properties and theorems. The truth in the axioms, theorems and properties remain coherent to the point that mathematics is considered as the language of creation for the scientist who is studying the laws of gravity or the geometry of chromosomes. The bible is an ancient book. Events are recorded in a chronological manner with reference to numbers and patterns are observed. This article aims to unveil some words and passages from the Bible which have a mathematical character infused in them. We will use the NIV version of the bible in most of the reference mentioned in this paper. In the following paragraph, we mention some few words or groups of words which carry a mathematical fragrance.

Keywords: numbers, hidden meaning of numbers, Bible

\section{Balance}

In Philippian 4:11, we see a statement made by Paul. I have learned to be content whatever the circumstances.

The meaning of "being content" is mathematically equal to "being balanced". When an equation is balanced, any quantity added to or subtracted from it, is actually distributed to the two sides. The end result is such that no side boosts having more. No side claims having less.

The bible tells us that God has blessed us with material things. Let the lack or the abundance of them not control us. We should keep balance.

In 1Peter2, 3 the concept of balance and equilibrium is stressed again in the statement: Give and you shall be given. Bless and you shall be blessed.

\section{Amen}

This word means: "so be it" or Let it become true. "remain as is for ever". An axiom in mathematics is a truth and will remain true.

\section{Limits are Set}

In Psalm 90, We can sense this idea of pattern. Life is a pattern. Limit for a lifespan are set. Every action counts for God. Today will soon be over, and tomorrow will soon be here.

With the mentioning of the distance between East and west, the Scriptures is referring to an endless situation. East and West cannot meet.

Psalm 90:3 mentions the expression "from everlasting to everlasting" which means "No time limit past, No time limit future". In Psalms 103: 12; He has removed our transgressions as far as the East is from the West. This is the idea of infinity $(\infty)$.

\section{The Wheel and the Knot}

The wheel is circular and the knot has no visible ends.

Many practical applications are direct result of esoteric mathematics. One example of this kind of applications is the knot theory to the study of the DNA. A knot is formed when the two ends of an intertwined string are made to vanish by being fastened together. 
God's word is eternal, thus has no ends. It is like a knot with its ends being sealed to the point the ends are inexistent like a wheel. Originally the bible was written in Hebrew language. The Hebrew alphabet has 22 letters, while the bible has 66 books. Imagine the 22 letters of the Hebrew alphabet being spread along a circle in the order from the first to the last. Now if we also spread the 66 books of the bible on the same circle and in the same order, we will be able to form three concentric circles. Three books of the Bible will fall on the same spoke of the now formed "wheel", whose representative is a letter of the Hebrew alphabet. Each of the three books on the same spoke relate to each other. They have in common the theme of what the letter stands for. A mathematical function of the type: $f(b o o k)=n+k 22$ can be formed. If we consider the Bible as a set of 66 books, we may define an equivalence relation. This relation has 22 equivalence classes, the "22 spokes of the wheel".

Where $\mathrm{n}$ stands for the numerical position of the book in the Bible. Example $\mathrm{n}$ for Genesis is $1, \mathrm{n}$ for Isaiah is 23 .

$\mathrm{K}$ is just a constant $(\mathrm{k}=0,1,2)$.

To find book on the same "spoke" or having the same theme as, we use this function.

Example: $\mathrm{f}$ (Exodus) $=2+0 \times 22=2 \mathrm{nd} ; 2+1 \times 22=24$ th; $2+2 \times 22=46$ th. That is $\{$ Exodus, Jeremiah, Corinthian 1$\}$.

Jeremiah is the 24th book, Corinthians 1 is the 46th book.

Books in the same class as Genesis are \{Genesis, Isaiah, Romans\}.

Concerning the book of Isaiah, It contains 66 chapters as many as the Bible does. In a way, Isaiah is like a bible inside the Bible. There are about 1189 chapters in the entire Bible. Therefore chapter in position 595th is in the middle and therefore the "median" of the Bible. This is found in Psalms 117 whose central theme is "Praise the Lord". Psalms 119 has 22 stanzas. Each of these has eight(8) verses. Because of the number 22 of chapters, Psalms 119 can also be called the chapter of alphabetic verses.

\section{The Wheel Rolled Away}

In Joshua 4:19, we read: when Israel crossed the Jordan river, they camped at Gilgal. They were circumcised and the reproach of Egypt was rolled away.

What could have rolled which is not circular like a wheel? The first and last letters in the Hebrew alphabet are respectively" Aleph" and "Tav". If Aleph and Tav are added in front and behind the word GILGAL a Hebrew or Aramaic word is formed, which is GOLGOTA, a name well known to most of us. The record of Gilgal is given in the book of Joshua. This name Joshua when translated into Greek in the Septuagint it is called lesous or Jesus (in English). The message in this passage is coded. This all code can be deciphered in this fashion: Gilgal needed the first and the last. (in other words, Jesus Christ) for it to become Golgotha where our sins were rolled away. This is a typical example of cryptography, a branch of mathematics. The message of the Bible is highly veiled, figurative; in short the language is encrypted. For example: Christians, male and female are being referred as the Bride of Christ. This is a figurative term representing all purified believers who are intimately related as one with the indwelling Christ.

In John 16:25 Jesus said .... The time is coming when I will no longer speak to you in figurative language. ... The rich understanding of the Bible is hidden in the Word of God

This message has a transformative power. For any transformation in mathematics, one needs the matrix behinds to understand the change taking place. For the Word of God, the understanding of the hidden truth requires the revelation by the One through whom the Word was written who is the Holy Spirit.

\section{What is Hidden Behind Numbers?}

The way and the number of times some numbers are used in the Bible indicates that there must be some numerical symbology to the use of numbers in the Scriptures. The consistency of the usage of some numbers testifies their meaning through the context of them being used.

Here are some instances where numbers are consistently used in the Bible: We will extract or give a meaning from the context they are being used.

\subsection{The number 2}

There are many instances where the number 2 is used in the Bible.

Numbers 35:30 and Deuteronomy 17:6

Matthew 18:19,20 and 2 Corinthians 13:1, Deuteronomy 19:15; John 8:17; Hebrew 6:17-18.

Every matter must be established by the testimony of two or three witnesses 
In all the above scripture reading taken from both the Old and New Testament, the number 2 is used to signify truth and agreement. Truth and God's church go hand in hand as they are witnesses of it.

\subsection{The number 3}

The number 3 is used over 466 times in the Bible. This points to the fact that this number has a spiritual significance. Let us consider some passages from which we may extract the meaning.

Exodus 10:22-23; Exodus 23:14,17; Isaiah 20:3, Genesis18:2; Samuel 21:1; Daniel 3: 24-25

Luke 23: 44-46; Mark 15:33 (3 disciples); Matthew 26:39-45; 1 Kings 18:34

In these passages and in others where the number 3 is used, it signifies God's Purpose and Will.

3 times Paul prayed concerning the thorn in his flesh but for no avail. It was God's Will and Purpose for it not to be removed.

Jesus Christ prayed three times for the cup to be taken from Him. It was God's Will and Purpose for Jesus Christ to go through Golgotha.

When 3 is used in conjunction with 2, the significance is the definition of the Church

As in Matthew 18:20: "For where two or three come together in my name, there am I with them."

\subsection{The number 4}

This number is that of the Compass directions (North, South, East, West). It is used a number of times in the Bible like in the following scripture passages:

Ezekiel 7:2: .... The end has come upon the four corners of the land.

\subsection{The number 12}

Jacob had twelve sons.

There were twelve tribes in Israel.

Jesus chose twelve Apostles.

Rev 12:1 12 stars, Rev 7: 5 144,000 sealed from each of the 12 tribes of Israel.

1 Kings 18:30 ....twelve stones..

The number twelve is referring of the government.

\section{Equality is Double Inclusion}

Two objects cannot be equal even though they may be similar.

Inclusion of a set $A$ into set $B$ happens when everything in $A$ belongs to $B$. When two sets $A$ and $B$ are equal, then there is double inclusion. That is : $A$ is included in $B$ and $B$ is also included in $A$. In other words Everything of $A$ is in $B$. Everything of $B$ is in $A$. Clearly this means that we are dealing with one set having two different names $A$ and $B$.

Let us consider three passages in the scripture: In Colossians 2:9 we read For in Christ all the fullness of the Deity lives in bodily form. That is Christ contains God in full.

Philippian 2:10: ..that at the name of Jesus Christ every knee should bow, in Heaven and on earth and every tongue confess that Jesus Christ is Lord.

John 14:9-11: Believe me when I say that I am in the Father and the Father is in me...

It is clear to see from these three passages of the scripture that God the Father is contained in Jesus Christ and Jesus Christ in God the Father. Therefore the mathematical principle of equality is satisfied.

\section{Dichotomy}

Dichotomy is observed in mathematics. It means either the property is satisfied or it is not. There is not a middle status. This is at the origin of the Boolean logics which is different from the fuzzy logics. In fuzzy logics for instance, an element may belong to a set partially. The Word of God says either live by sight or live by faith.

Similar to the Boolean logics where either the value of a proposition is 1 for truth or it is 0 for wrong. No proposition is both true and false. These two possibilities are mutually exclusive. The occurrence of one guarantees the nonoccurrence of the opposite result for the other. 
Either be or do this, but not be in both sides in the same time. Fuzziness is not found in the word of God. Never should it be found in God's people's minds.

This principle is rigorously enforced in the Bible. The following passages confirm it.

Matthew 6:24: No one serve two masters. Either he will hate the one and love the other, or he will be devoted to the one and despise the other. You cannot serve both God and Money.

Ecclesiastes 5:10: Whoever loves money never has money enough...

Revelation 3: 15-16:... you are neither cold nor hot. I wish you were either one or the other...

Matthew 21:21 and Mark 11:23, 2Kings 7: 1-2. Here Doubt is opposed to faith. Without faith no one can please God.

James 5:12 Let your "Yes" be yes, and your "No, no, or you will be condemned.

James 1:5-8: ..." That man should not think he will receive anything from the Lord. He is a double-minded man, unstable in all he does".

Thus God rejects ambiguity, a double standard situation.

\section{The Principle of Transitivity}

Let $A, B$ and $C$ be three entities. If What $A$ is or does to $B$ is exactly what $B$ is or does to $C$. This relationship is said to be transitive If $A$ is or does the same thing to $C$.

God is my Father and I am a father to my son. God is not a grandfather to my son. Rather He is Father to my son as well. The Fatherhood of God to us is transitive. In Genesis 12:3, ... I will bless you...I will bless those who bless you. Blessing is therefore transitive.

\section{The Exponential Increase}

In Genesis 15:5; Genesis 47:27; Acts 2: 47. God has set in motion the exponential growth of His church.

\section{Concluding Remarks}

As we look through this mirror, the Word of God, we see but just a glim. The little we manage to perceive is of such a mathematical precision. Words are carefully chosen in the text of the Bible. Even the order at which different books which were written in different periods are put together has an astonishing precision, which also reveal the mathematical characteristics of the Bible. We do not mean that the Bible follows the laws of mathematics. We are merely trying to say that mathematics is a precise discipline as the text in the Bible is.

\section{References}

Meyer: bread upon waters, Radio Pulpit, Pretoria

Smith, Williams "entry for Gilgal", Smith's Bible dictionary 1901.

Tony Warren, the numbers in the scriptures, https://www.mountainretreatorg.net/Bible/numbers.html 